Portland State University

PDXScholar

$1-1-2010$

\title{
Fair Trade Standards, Corporate Participation, and Social Movement Responses in the United States
}

\author{
Daniel Jaffee \\ Portland State University, jaffee@pdx.edu
}

Follow this and additional works at: https://pdxscholar.library.pdx.edu/soc_fac

Part of the Food Studies Commons, and the Politics and Social Change Commons Let us know how access to this document benefits you.

\section{Citation Details}

Jaffee, Daniel, "Fair Trade Standards, Corporate Participation, and Social Movement Responses in the United States" (2010). Sociology Faculty Publications and Presentations. 133.

https://pdxscholar.library.pdx.edu/soc_fac/133

This Post-Print is brought to you for free and open access. It has been accepted for inclusion in Sociology Faculty Publications and Presentations by an authorized administrator of PDXScholar. Please contact us if we can make this document more accessible: pdxscholar@pdx.edu. 


\title{
FAIR TRADE STANDARDS, CORPORATE PARTICIPATION, AND SOCIAL MOVEMENT RESPONSES IN THE UNITED STATES
}

\author{
Daniel Jaffee ${ }^{1}$
}

This is the Accepted Manuscript (Author's Post-print) of an article published in the Journal of Business Ethics. Available online: https://doi.org/10.1007\%2Fs10551-010-0583-1

Citation: Daniel Jaffee. 2010. "Fair Trade Standards, Corporate Participation, and Social Movement Responses in the United States." Journal of Business Ethics 92: 267-285.

Doi: 10.1007/s10551-010-0583-1.

\begin{abstract}
This article examines the development of and contestation over the standards for certified fair trade, with particular attention to the U.S. context. It charts fair trade's rapid growth in the United States since the 1999 advent of formal certification, explores the controversies generated by the strategy of market mainstreaming in the sector, and focuses on five key issues that have generated particularly heated contention within the U.S. fair trade movement. It offers a theoretical framework based in the literatures on agrifood systems, social movements, and public-choice economics, for understanding the corporate response to alternative markets such as fair trade. The article suggests a typology of responses by social movement actors to this increased corporate participation, and assesses the relevance of the U.S. case for the future prospects of fair trade, both in other national contexts and as an international movement.
\end{abstract}

\footnotetext{
${ }^{1}$ Department of Sociology, Portland State University, Portland, OR, USA. Email: jaffee@pdx.edu
} 


\title{
FAIR TRADE STANDARDS, CORPORATE PARTICIPATION, AND SOCIAL MOVEMENT RESPONSES IN THE UNITED STATES
}

\author{
Daniel Jaffee
}

\section{INTRODUCTION}

On October 28, 2008, Starbucks Coffee announced a new partnership with the U.S. fair trade certifier Transfair USA and the international certification body Fairtrade Labeling Organizations International (FLO). As part of the arrangement, Starbucks promised to increase its purchases of fair trade certified coffee to 40 million pounds per year, roughly doubling its current purchases and making the roasting giant the world's largest single buyer of fair trade coffee. "This dramatic volume increase will have a far-reaching positive impact in coffee growing communities throughout the developing world," boasted Transfair USA's CEO Paul Rice. "It will send kids to school, bring clean water to farming communities and enable struggling farmers to put food on the table ... Starbucks Shared Planet initiative empowers consumers to make ethical decisions about the coffee they drink, and support the farmers that produce it." According to the announcement, the deal positions Transfair and FLO as "key partners in the Starbucks Shared Planet commitment to ethical sourcing" (Transfair USA 2008e). As part of the deal, Starbucks, Transfair USA and FLO-Cert "plan to develop a single audit system for farms applying for both Fairtrade certification and Starbucks Coffee and Farmer Equity (C.A.F.E.) Practices verification" (Transfair USA and Starbucks Coffee 2009).

The response to the announcement from participants in the fair trade movement was mixed. Some fair trade activists expressed enthusiasm that after nine years of participation in the fair trade system, Starbucks had finally agreed to raise its fair trade purchases to over ten percent of its total supply, but other long-time participants were more skeptical. Dean Cycon, 
the owner of fair trade coffee roaster Dean's Beans, responded that "fair trade is about transparency and accountability, but up to now Starbucks has not been either .... The C.A.F.E. standards are pretty mysterious, and ... the company is notorious for massaging what really goes on under those standards" (Patriana 2008).

The Starbucks/Transfair USA/FLO "partnership" encapsulates both the successes and dilemmas facing the growing fair trade movement in the United States. On one hand, growing consumer interest in fair trade products has drawn the attention and participation of large corporate agrifood firms, whose purchases have substantially increased the volume of fair trade sales, heightened the visibility of the movement, and augmented the financial benefits flowing to producers and waged laborers. On the other hand, such close collaboration between a certifier and one of its corporate licensees - that is, between fair trade's national regulatory body and the party it is charged with regulating-bolsters charges by some critics that the certifier has lost distance and independence from the large commercial firms that represent an increasing proportion of fair trade volumes (and certifier revenues), even while sourcing only a small proportion of their total supply at fair trade terms. The prospect of increased integration between the independent, third-party fair trade standards and Starbucks' own first-party C.A.F.E. Practices standards also raises other concerns, including the possibility of the weakening of the former.

What are the motivations of large corporate firms that choose to engage with standardsbased alternative market systems such as fair trade? Corporate entry into the fair trade market has generated a considerable degree of debate and discord among the actors who worked to create this alternative market in the first place, and in many cases movement activists have explicitly opposed corporate involvement. Yet what is the nature of these activist responses; 
how specifically do movement advocates work to protect the integrity of the standards or to keep them from being watered down? Can this be done while still broadening the impact of these efforts and reaching a mainstream consumer base? This article addresses these and other related questions through a case study of the U.S. fair trade movement and market, focusing on the phenomenon of corporate involvement — not merely in the retailing of fair trade certified goods, but in the processes of negotiating, establishing, enforcing and reformulating the standards and certifications undergirding this initiative - as well as the responses by social movement actors to that increased involvement.

Many observers have examined the increasing corporatization of "alternative agrifood networks" such as fair trade and organic agriculture (e.g., Allen and Kovach 2000; Guthman 2004a), and the risks and benefits of the strategies of market mainstreaming adopted by these movements. Others have explored the responses in the realm of advertising and public relations by agribusiness, distribution and retailing firms to the challenges posed by the standards and third-party certifications that underlie these alternative market systems, responses which have often been categorized as "greenwashing" or "fairwashing." M. Fridell et al. (2008: 23) argue that such responses collectively represent a "corporate countermovement" against the regulatory impact of such agrifood schemes. However, with a few exceptions focused on organics (e.g., DuPuis and Gillon 2009), there has been virtually no examination of how large commercial firms have affected the actual shaping of these standards and rules themselves, nor an exploration of the manner in which this process has unfolded in fair trade. Likewise, limited attention has been paid to the ways that social movement actors have responded to these threats and challenges in attempting to retain or reassert the original transformative character of the fair trade system. 
This article examines the development of and contestation over the standards for certified fair trade, with particular attention to the U.S. context. It briefly charts fair trade's rapid growth in the U.S. since the 1999 advent of formal certification, explores the controversies generated by the strategy of market mainstreaming in the sector, and focuses on five key issues that have generated particularly heated contention within the U.S. fair trade movement. It offers a theoretical framework based in the literatures on agrifood systems, social movements, and public-choice economics, for understanding the corporate response to alternative markets such as fair trade. Since their inception, fair trade standards have undergone numerous changes, which can be categorized into three related processes: the cooptation of the most transformative or redistributive elements of the original movement initiatives, the at least partial regulatory capture of the institutions charged with applying the standards, and the dilution or weakening of those standards. Cross-cutting all of these phenomena has been a progressive sidelining of the deeper and more comprehensive social justice critiques that had underlain the fair trade initiative from its inception.

\section{STANDARDS AND CERTIFICATION IN ALTERNATIVE AGRIFOOD SYSTEMS}

The dramatic changes wrought by economic globalization upon agrifood systems have been charted by a wide range of scholars, and among the recurring themes is the rise of standards and certifications as a new form of governance. Busch and Bain (2004) chart the emergence of private food standards, particularly those created by retailing firms, that they assert now play a greater role than either states or supra-state bodies such as the WTO in reshaping our food systems. This move from public to private standards reflects the retreat of the state from the regulation of capital generally, as part of a broader shift from Fordism to neoliberalism over the past three decades. Concomitant with these shifts are fundamental changes in the nature of food 
commodity chains, including a move from what Gereffi, Korzeniewicz and colleagues (1994) term "producer-driven" chains controlled by large production firms, toward "retailer-driven" chains dominated by distributors and chain retail firms.

At the same time, there has also been a rise of standards located in non-governmental, civil society networks and initiatives. Fair trade is perhaps the most prominent of these, having evolved its own international certification system. Such independent standards—while they often were developed explicitly to counter the deleterious social and ecological effects of food system globalization — can also be viewed as an artifact of the neoliberal turn away from public regulation. At the same time, however, other important standards regimes are still firmly located within a state framework (such as the 2001 USDA organic standards) or a supra-state rubric (e.g., the European Union standards for organic food). Raynolds and Wilkinson, utilizing a typology developed by Gereffi et al. (2005), distinguish between "captive" chains, in which "producers are firmly controlled by processors and retailers often through contracts," and "relational" commodity chains such as those in fair trade, in which transactions are based on trust and the sharing of power and information across a network (2007: 36).

Yet even these state-based and independent NGO standards regimes—which ostensibly respond primarily to the interests of social movements, consumers, and small producers, rather than those of capital—remain susceptible to broader pressures. Mutersbaugh (2005a: 20332035) argues that all agrifood standards are currently undergoing a process of globalization, in which the content of national, sectoral, and even civil society standards is progressively being altered as they become "harmonized" with evolving transnational regulatory regimes, such as the International Organization for Standardization (ISO) norms and WTO sub-agreements such as TRIPS (Trade-related Intellectual Property Rights). Mutersbaugh provocatively describes this 
trend as a "corporate social movement" against the restrictions to the freedom of capital posed by non-corporate standards. In other words, even the "relational" chains that characterize these more progressive initiatives are in danger of becoming "captive" to prevailing market forces.

The predominant way in which compliance with agrifood standards is verified is through certification, and the claims underlying these certifications are typically translated to consumers in the form of product labels. The nature of the certification systems underpinning standards can be conceptualized in various ways. Renard (2005a: 419) asserts that the power of certification rests upon the ability to define particular qualities related to goods and specific practices (in production, trading, processing, etc.), and by extension, to define which products do not meet such definitions. "These practices," she writes, "constitute, in effect, mechanisms of market entry and exclusion, converting them into a source of power for those who control them." DuPuis and Gillon (2009: 8) call attention to this "boundary-setting" process as a key element in establishing identity and credibility for alternative agrifood markets, and describe the conflicts that can arise when other actors challenge the legitimacy of those certification boundaries.

Another theme in this literature is the contestation between civil society and the market over the specific content of standards and certification in alternative agrifood alternatives, although the bulk of the discussion has focused on organic standards. Some authors have examined the increasing contestation over fair trade standards and governance as corporate actors have entered the sector, unleashing struggles with the pioneering social movement players (e.g., G. Fridell 2007; Jaffee 2007; Renard and Perezgrovas 2007). A few writers have focused on the fair trade and organic systems in tandem to illustrate the larger shifts toward standardsbased regulation in the agrifood system generally (See Mutersbaugh 2005b; 2005a; Raynolds and Wilkinson 2007; Jaffee and Howard forthcoming). 
Yet despite this burgeoning literature, there has been virtually no meaningful attention to the specific processes by which mainstream market actors have attempted variously (and often simultaneously) to join, beat, and ignore the fair trade alternative, and to defuse the threats it might represent to their conventional industry practices. Analyzing these strategies deployed by the dominant market firms can yield valuable insights into the types of responses that social movements might find most effective.

\section{CO-OPTATION, CAPTURE, AND DILUTION}

How should one make sense of the choices made by these large commercial players, who in many cases opt to "join the game" in alternative agrifood markets - taking advantage of the profits offered by these niches and the integrity they represent to consumers - while often also working to neutralize the transformative power of the standards underpinning that integrity? I have already explored one set of analytics from the literature on the political economy of agrifood systems, including the globalization/harmonization of standards and "boundary conflicts." Yet while quite useful, these frames do not offer a sufficiently strong lens with which to understand the specific practices that capital utilizes in its quest to render the standards less of a threat. Here it is useful to turn to conceptual frameworks from other arenas, including social movement literature focused on co-optation, and the public choice literature on the economics of regulation that examines regulatory capture.

Cooptation. The concept of cooptation was most extensively developed in the sociological literature on U.S. social movements. While it originally referred principally to "the process of absorbing new elements into the leadership or policy-determining structure of an organization as a means of averting threats to its stability or existence" (Selznick 1949), the term has more recently been expanded to refer to three related but distinct processes, each of which describes 
the ways that states or government entities work to neutralize the power of movements for social change. The first is a process by which states aim to divert the goals or demands of a social movement or group to serve different, less transformative agendas. Second, movement activists may be coopted into "working from within" the state - or merely cooperating with state actorsin order to achieve some portion of their original goals through officially sanctioned means (Gamson 1968; Gamson 1975). The term has also been used in a third sense to refer to a process by which the state appropriates the language, slogans, tactics or strategies of a movement, thereby aiming to divert them toward less radical ends.

However, using such theoretical frameworks in the context of this article raises a few important questions. Is it appropriate to apply the concept of cooptation-which has been most fully elaborated in the context of U.S. social movements (particularly the civil rights movements of the 1950s and 1960s), whose efforts were focused on changing state policy and law — to the sphere of agrifood systems, and to the much newer context of consumption-based "movements" such as fair trade, aimed at achieving change through the marketplace, and especially to cases where regulation and policy-setting does not occur in the public sphere? Can this theory meaningfully be used to analyze situations in which industry, not the state, aims to weaken social movement demands, or in which non-state bodies play the central regulatory function?

Several observers have answered these questions in the affirmative. Campbell (2001) examines the sustainable agriculture movement in California as a case study of political cooptation, emphasizing the tensions that movement leaders encountered "between conviction and credibility" in choosing whether or not to work with state officials in developing new programs and policies. Social movement goals can also be embodied or codified in the form of standards, and these standards too are susceptible to cooptation. Thompson and Coskuner-Balli 
likewise view "the corporatization of the organic food movement [as] an example of cooptation" (2007: 135), although these authors emphasize market appropriation of the countercultural practices and symbols of that movement. Unlike the U.S. organic sector, however, where since 2001 the state has been the locus of standards formation, in fair trade the standards are formulated by a non-governmental entity, originally emerging from civil society, yet one also vulnerable to (and capable of generating) similar pressures.

Regulatory Capture. The related concept of regulatory capture helps to shed additional light on these dynamics. The concept originally emerged from public-choice economic theory and in particular the work of economist and Nobel laureate George Stigler (1971). Capture occurs when actors with a vested interest in the outcome of regulatory decisions aim to influence the bodies charged with making those regulations, and when those bodies, rather than protecting the public interest, instead operate to the benefit of the commercial or special interests they are charged with regulating. The distortion of the regulatory function of federal agencies under recent U.S. administrations, both Republican and Democratic, provides abundant evidence of such capture. More recent literature on capture has also placed emphasis on the role played by other interest groups - e.g., consumers and environmentalists - in working to affect regulatory agendas (Laffont and Tirole 1991).

Goodman and Goodman, describing the development of organic standards in California and the response by agribusiness firms, conclude that "this regulatory capture has forced progressive, more politicised organic imaginaries to the margins" (2007:3). However, while the state-regulated U.S. organic sector clearly fits the framework for studies of capture, does fair trade provide an equally appropriate application of these concepts? Do the non-profit international certification bodies Transfair USA and Fairtrade Labelling Organizations 
International (FLO) qualify as regulatory "agencies"? Increasingly, the literature on standards refers to the application of both civil society and industry-generated standards as a regulatory function (See for example Mutersbaugh 2005a; Renard 2005b; Renard 2006; Fridell 2007; Raynolds, Murray and Heller 2007). As the rest of this article illustrates, independent certification and standards-setting bodies are no less susceptible than their state-based regulatory cousins to hijacking by a set of interests opposed to those they are charged with protecting.

Dilution. In addition to cooptation and capture, there is a third analytical lens that can aid in understanding the trajectory followed by the fair trade sector: standards dilution. Dilution is a by-product of regulatory capture which focuses attention on the ways that industry involvement weakens standards, aiming in many cases to lower the bar to entry, thus allowing the certification of actors and practices that would have previously been impermissible.

Several observers of the political economy of fair trade have used the analytic of weakening or dilution. Marie-Christine Renard discusses the risk of corporate entrants "diluting minimum social-justice standards" that underpin fair trade, as well as what she terms "Starbucks' standards-dilution strategy" toward the fair trade system (2005a: 420, 425). M. Fridell et al. assert that because Northern fair trade advocates have failed "to publicly criticize the underlying structure of capitalism" that generates the deep asymmetries in global trade, "fair trade becomes more vulnerable to brand dilution" by the new corporate entrants (2008: 30).

Such strategies of standards weakening or bar-lowering, it must be noted, set up an important contradiction: permitting the entry of low-road competitors (who would previously have been excluded) clearly threatens to reduce the potential rent or price premium to be gained from the niche, not to mention consumer confidence in the initiative (Guthman 2004a; 2004b; Mutersbaugh 2005a). I now proceed to examine in greater detail the way these processes of 
movement co-optation, standards dilution, and regulatory capture have played out in the U.S. fair trade sector.

\section{Contestation Over Fair Trade Standards in the U.S.}

This section discusses several key areas of contestation within the U.S. fair trade movement coalition, focusing on how each of these issues intersects with the processes outlined above. Many accounts describe the fair trade system in the United States as a largely successful story of the use of standards and certification to dramatically expand an alternative or ethical market, reaching a mainstream consumer base through mass-market retail channels, and redistributing capital to disadvantaged Southern producers through minimum prices. Others, however, read the story of fair trade in the U.S. as a cautionary tale, involving the capture of an alternative market by large corporate firms who succeed in weakening its standards, and the diminution of the movement's transformative power. Both versions of the story, I argue, contain substantial elements of truth.

Much like its predecessors in Europe, the U.S. fair trade movement initially was characterized exclusively by the Alternative Trade Organization (ATO) model, in which goods from producer cooperatives are sold through non-profit organizations or ethical for-profit businesses (Raynolds and Wilkinson 2007: 36). Church-based networks of craft sales, led by the Mennonite-affiliated Ten Thousand Villages, and later SERRV, linked with the Church of the Brethren, developed between the 1940s and 1970s to generate markets for the products of impoverished U.S. communities, and displaced and refugee groups abroad. Boston-based Equal Exchange coffee, founded in 1986, pioneered the fair trade model for agricultural products in the U.S., filling this niche virtually alone for a decade. Equal Exchange initially circumvented the U.S. commercial embargo against Nicaraguan coffee, finding a market among progressive 
consumers through retail grocery cooperatives, and expanded to work with coffee farmer cooperatives in many other coffee-growing nations. The young U.S. fair trade movement thus shared with its European counterparts a twin set of roots: one in religious development charities and another in solidarity activism on the political Left.

While the structures undergirding fair trade certification had developed in many European countries by the early 1990s, formal fair trade certification in the U.S. began only in 1997 with the creation of Transfair USA. Transfair was initially housed in the Minneapolis-based NGO Institute for Agriculture and Trade Policy, but in 1999 it moved to Oakland, California and became an independent non-profit entity. The U.S. movement quickly began to encounter the dilemmas and tensions associated with growth: was it possible to reach mass consumer audiences (as opposed to the more politically active "conscious consumers") with fairly-traded goods while still hewing closely to the core values of fair trade, which emphasize building direct, long-term trading relationships and alternative trading structures? While many of the national fair trade initiatives in Europe emerged out of development activism and NGO circles, since its 1999 move Transfair USA has been characterized by a business-centered model, and civil society links have played a minimal role in its institutional culture and governance structure.

The corporatization of fair trade arguably began in 2000, perhaps ironically as the result of an activist campaign targeting the multi-billion-dollar specialty coffee giant Starbucks, which had been targeted by international labor rights groups for its global labor and pricing practices. The San Francisco-based Global Exchange and a coalition of other NGOs insisted that Starbucks purchase and offer fair trade certified coffee, viewing it as a mechanism to leverage greater corporate accountability. Shortly before they were to launch simultaneous protests in a number of cities, the company relented and agreed to sell fair trade coffee in all of its (then 2,300) U.S. 
stores. Since this development, several other large coffee firms have entered the fair trade market, among them specialty roasters such as Green Mountain Coffee and mass market coffee giants including Procter \& Gamble. While some of these firms were pushed into the market by activist campaigns, others were pulled by the lucrative potential of this growing niche market and/or active recruitment of mainstream firms by Transfair USA, as well as the very flexible conditions of entry.

This mainstreaming strategy has proven quite effective at raising consumer demand for fair trade: the U.S. fair trade market experienced annual volume growth of at least 35 percent in every year except 2007 and is now the largest national fair trade market, exceeding \$1 billion in sales in 2007 (FLO 2008; Transfair USA 2008d; Transfair USA 2009). As of the end of 2008, 260 producer organizations sold fair trade certified goods to the U.S. market, collectively receiving over $\$ 10.8$ million in social premium payments and $\$ 34.6$ million above the conventional market price, according to Transfair USA (2009). Although the certifier announced in 2008 that it plans to dramatically expand its range of offerings to dozens of new products, primarily fresh and dried fruit, nuts and spices (Transfair USA 2008b), coffee still accounts for the large majority of the U.S. fair trade market, with over 87 million pounds imported in 2008 from 152 producer organizations. Of the 779 companies licensed by Transfair to import fair trade certified goods, 512 are coffee roasters and/or importers (Transfair USA 2009). A substantial portion of the growth between 2007 and 2008 was due to increased purchases by large transnational firms, primarily Starbucks (which went from 11 million to 20 million pounds, roughly six percent of its total volume). 


\section{Key Debates in the U.S. Fair Trade Context}

There has been a vigorous ongoing debate within the U.S. fair trade movement regarding the benefits and drawbacks of the system's mainstreaming or corporatization. However, what many participants may not have anticipated at the movement's inception in the U.S. was how the large agrifood corporations entering the fair trade market would use their market power to push for changes in the actual "rules of the game" in order to reduce or eliminate the challenge posed by the standards to their existing pricing, labor and commercial practices. In their discussion of the rise of non-state regulation, Raynolds et al. distinguish between standards that "raise the bar," leading to improvements in social and environmental conditions, and those that "hold the bar," merely preventing further degradation $(2007: 148,150)$. While they include fair trade standards in the former group, the current context of fair trade in the U.S. can be described as one in which there is considerable pressure from the new corporate participants to (once again) lower the (raised) bar.

These pressures have played out in at least five key areas, which I will proceed to examine in greater detail: 1) the distinction between "movement-oriented" and "market-oriented" fair trade retailers; 2) the relationship of Transfair USA to these two groups of licensees, including the question of minimum entry requirements for licensing; 3) the level of fair trade minimum prices; 4) the increasing certification of plantation agriculture; and 5) issues of fairness along the supply chain, as well as how best to manage market growth. While only some of these issues are unique to the U.S., the struggles have played out in a distinctive form within the U.S. context, and some of the results have been determinative for the global fair trade movement and market as a whole. 


\section{Market-oriented versus Movement-oriented Retailers.}

The fair trade movement was pioneered by small, ideologically-driven ATOs and cooperative businesses, selling entirely or largely fair trade products and with histories of longterm involvement with producer groups and communities. However, fair trade has increasingly drawn the participation of larger mainstream retailers, including some of the largest agrifood corporations. Whether pulled in by the potential for profit in the increasingly lucrative fair trade niche or pushed by grassroots activists seeking to leverage fair trade as a corporate accountability tool, this new group of "market-oriented" retailers comes to the table with a very distinct set of motivations, and a different level of market power, than the "movement-oriented" companies. Several academic observers have discussed this distinction and its implications for the movement's development (e.g., Tucker 2006; Fridell 2007; Fridell et al. 2008; Reed 2009) . Raynolds (2009) describes three groups: in addition to "mission-driven" and "market-driven," she also identifies a "quality-driven" group of retailers that selectively engage with fair trade primarily to access supplies of high-quality products. In addition to corporate roaster-retailers such as Starbucks, fair trade certified products are increasingly sold by large retail chains such as Wal-Mart and Costco under their store brands, and by large restaurant chains, including McDonalds and Dunkin Donuts. ${ }^{2}$

Over the past nine years, the difference between these two groups of retailers has become the most significant issue confronting the U.S. fair trade movement. The question of the desirability of allowing large corporate firms to participate in this alternative market has increasingly riven the movement. Many social movement activists view the development as a threat to the guiding principles of fair trade. "We cannot let our radical vision of a completely

\footnotetext{
${ }^{2}$ Some observers (e.g., Reed 2009) argue that the sales of fair trade products through mainstream corporate retailers (e.g. Wal-Mart or McDonalds) is a distinct issue from - and less contentious within the movement than - the direct licensing of corporate roaster-retailers or processors such as Starbucks or Procter \& Gamble.
} 
different way of doing business be watered down by opportunistic transnationals," writes Albert Tucker. "The fair trade mark should be regarded as a 'badge of honor,' not just a brand of food that demonstrates you are paying a little more to desperate farmers... if any transnationals are involved, they must negotiate with poor farmer businesses on an equal basis, having signed up to stringent standards across their entire operations" (Tucker 2006: 9). Yet some other pioneering fair trade activists take a different stance; Pauline Tiffen, the founder of Cafédirect and Divine Chocolate, argues that 'for better or worse, as soon as Dunkin' Donuts has fair trade espresso, it does open doors. It's a mistake to discount the impact of things just because you don't agree with the motives of the people doing it" (quoted in Tucker 2006).

2) Transfair USA's Relationship to Market and Movement Participants.

While highly contentious, the entry of corporate licensees into the fair trade system has indisputably increased the volume, variety and visibility of fair trade certified products in the marketplace. A substantial part of the dramatic growth in fair trade sales in the U.S. can be attributed to increased purchasing by corporate licensees. However, some fair trade participants argue that the growth imperative has facilitated cooptation, as the regulatory function of FLO and the NI's clashes with an economic interest in increasing demand. They often point to the groundbreaking certification deal between Transfair USA and Starbucks as emblematic of these contradictions.

The first significant instance of cooptation and dilution in the U.S. fair trade setting was the decision to lower the bar for entry into the certification system. In Transfair USA's initial two years, there was negotiation over the minimum participation level that would be required to enter fair trade. The directors of Equal Exchange recommended to Transfair that in order for a company to place the fair trade seal on any of its products, at least five percent of its total 
purchases must be made at fair trade terms from cooperatives on the international fair trade register. “Our thinking,” writes Equal Exchange's Rodney North,

was that this would help ensure long term commitments, and not merely token participation....We suggested a staggered formula, that recognizes the real-world, operational constraints faced by large businesses. Therefore we proposed that the bigger a business, the lower the initial Fair Trade percentage they would have to commit to in order to use the seal. On this scale 5 percent was the lowest hurdle... and we believe that we got a commitment from Transfair to require the 5 percent. However, what happened in practice seems to be that Transfair simply encourages companies to work toward 5 percent. Further, we also encouraged that the bar be raised steadily over time... of course since we didn't get the 5 percent, we didn't get the 'bar raising' requirement either (quoted in Green LA Girl 2006).

Transfair's position became clear when it brought Starbucks to the negotiating table: the coffee giant entered the $\mathrm{FLO} /$ Transfair system in 2000 with approximately one percent of its purchases at fair trade terms.

Since 2000, some of the mass-market coffee transnationals (among them Procter \& Gamble and Sara Lee in the U.S.) have also struck deals to enter the system while purchasing very small amounts of coffee- less than one percent of their total volume - at fair trade terms. Transfair USA still does not stipulate any particular purchase level to qualify for use of the seal, nor is there a requirement for increases over time; these details are negotiated in private deals with individual firms. The certifier's website makes its position on this issue clear: "[p]articularly for large companies, it is unrealistic to expect them to convert large portions of their overall business to Fair Trade overnight, before demand has been proven ... If we take a rigid approach with regard to minimum volumes or percentages - presumably in defense of the credibility of the label — we could potentially lose significant volume to the detriment of the farmers we seek to serve" (Transfair USA 2008c). Yet without a requirement for firm minimum (and rising) purchasing levels, fair trade risks being used by corporations to engage in "fair-washing," reaping substantial image benefits while engaging with fair trade at merely token levels. "By 
opening its social claims to mainstream retailers while simultaneously pushing for large volume sales," write Holt-Giménez et al. (2007: 15), "Fairtrade has left itself open to a public relations coup by corporate free riders." These firms clearly see fair trade as a profitable niche and a useful corporate social responsibility tactic, but the critics argue that the certifier has a responsibility to force corporations to go beyond this niche, instead using fair trade as mechanism to leverage greater corporate accountability. Moreover, charge the movementoriented retailers, the large firms who dabble in fair trade at token levels are able to subsidize the additional costs of their fair trade purchases with profits from their conventional sales, thus undercutting the retail prices of the 100-percent fair trade firms, who are not able to externalize their social costs in a similar fashion (Reed 2009: 12).

The global fair trade certifier FLO has been the locus of struggles over both the relative power of movement and market forces, and of Northern versus Southern interests, within the international fair trade system (Renard and Perezgrovas 2007: 149). To a degree, these same concerns have been directed at Transfair USA as well. Because licensing fees follow volumes, the large firms make an increasingly substantial financial contribution to Transfair. Licensing fees accounted for 64.7 percent of Transfair's revenues in 2007, the last year for which data are available (Transfair USA 2008f). The fees paid by Starbucks alone in 2008 for its 20 million pounds of fair trade coffee (approximately six percent of the coffee it roasted under its own brand name ${ }^{3}$ ) thus account for approximately 17 percent of the certifier's operating budget. This poses a dilemma: while an alternative to volume-based payments would be difficult to identify, they do create a structural dependency upon these large firms, as well as a disincentive to take policy decisions that might alienate a large licensee. Identification by regulators with the interests of the regulated party is a key element of capture. The recent announcements by

\footnotetext{
${ }^{3}$ Starbucks also purchases and roasts coffee for other firms (such as Costco's Kirkland store brand).
} 
Transfair of its certification "partnership" with Starbucks blurs the lines between regulator and regulated even further, and raises questions about the certifier's ability to remain independent and rigorous.

Another question concerns the representation of different constituencies on the decisionmaking body or bodies. After substantial lobbying by fair trade producers, FLO recently made changes to its organizational structure that give greater voting power to Southern producer groups, although they still constitute a minority of the board and committees. At Transfair USA, on the other hand, there have been no major governance reforms. According to Reed (2009: 21), "key constituencies, such as ATOs and advocacy groups, feel that they are not (adequately) represented on the boards of the [national certfication initiatives or NI's]. In this context, some [NI's], perhaps most notably TransFair USA, have come under sharp criticism for not upholding a commitment to fair trade values and practices and for not listening to the concerns of actors in the fair trade movement." A look at the composition of the initiative's board of directors (Transfair USA 2008a) indicates that five of the 12 board members come from the corporate or finance sector (including the former CEOs of Archer Daniels Midland Cocoa and Ocean Spray Cranberries), three come from the non-profit sector (from large NGOs and foundations), two are consultants (one with an academic affiliation) and one is the CEO of Transfair USA. The sole "producer" on the board is the general manager of a large coffee cooperative federation in Costa Rica. Among the significant sectors of the fair trade movement that are not represented on the Transfair board are fair trade NGOs or civil society groups (e.g. Global Exchange), membershipbased fair trade groups (e.g., United Students for Fair Trade or the Fair Trade Federation), faithoriented groups with substantial fair trade programs (e.g. Catholic Relief Services or Lutheran 
World Relief), small and medium-sized fair trade retailers, or producers who were democratically elected to represent fair trade farmer interests.

After receiving withering criticism in 2005 from fair trade activists and small producer organizations for excluding them from negotiations over a certification deal with U.S.-based banana giant Chiquita (see below), Transfair agreed to engage in a dialogue with an ad hoc group of social movement NGOs about its relationship with corporations. Emerging from these consultations was a set of guidelines, which address obliquely the issue of minimum volumes, and indicate the certifier's preference for a voluntary, negotiated approach with its corporate licensees:

Transfair encourages companies to make a strong investment in the success of their Fair Trade product offerings...to avoid the perception of 'greenwashing,' companies should seek media coverage that is commensurate with their actual volume and involvement with Fair Trade Certified products. If a company appears to be using PR or advertising ...to inflate its public image in a way that is disproportionate to its actual investment in Fair Trade, Transfair will engage the company in question to seek greater balance between word and action" (Transfair USA 2008g).

This approach is in stark contrast to the position of the movement-oriented retailers. Equal Exchange's Rodney North argues that "even a tiny bit of fair trade can go a long way to polishing even the worst corporate image, and all at the expense of real reform... the same rules that allow Nestlé to put on a fair trade fig leaf in the U.K. market, apply in the U.S. as well. And that's why we at Equal Exchange are speaking out, because we see this as the latest in a long line of actions by the world's largest food businesses that look good in isolation, but ultimately forestall real change for impoverished farmers" (North 2008).

\section{3) Minimum Prices.}

While fair trade prices and social premiums are set at the international level by FLO, the level of the minimum prices — primarily for coffee- has become a major point of contention 
within the U.S. movement, in particular between the small movement-oriented roasters and the large firms. For coffee in particular, the minimum prices had been raised only minimally since they were established in 1989 , steadily losing purchasing power to inflation. As the global coffee crisis receded in 2005 and 2006, movement-oriented firms increasingly found that many of the coffee farmers they worked with could not break even—let alone come out in the blackwith the FLO minimum prices, because their costs had risen while the base price stagnated. Rather than bringing these small farmers out of poverty, fair trade was further impoverishing them. These small roasters - along with several producer associations - began to lobby for an increase in the FLO minimum prices.

A study by Bacon et al. (2006) documents that real fair trade coffee prices (adjusted for inflation) fell by 39 percent between 1988 and $2005 .{ }^{4}$ The minimum prices are important because they represent the sole way in which fair trade redresses the unjust distribution of returns along the commodity chain. To the extent that minimum prices do not keep pace with increases in producer costs, the initiative is actually shifting capital further away from producers toward the retail end of the chain. "Fairtrade's efficacy as a safety net [for producers]," argue HoltGiménez et al., "is eroding because it is based on a premium price that no longer provides a living wage" (2007: 19).

The base prices for fair trade products (at first only coffee) were initially established by movement NGOs in the late 1980s based on assessments of producers' costs and livelihood needs. Individual buyers may pay higher than the FLO minimums if they choose. The setting of prices became the purview of FLO after its creation in 1997. Prices are thus an integral part of FLO standards, one of the most important. A "fair price" was the raison d'etre for fair trade's

\footnotetext{
${ }^{4}$ This calculation used only the U.S. Consumer Price Index; the loss of purchasing power in most producer countries has been greater.
} 
creation, and it is arguably upon the premise of a fairer price that the moral power of the system continues to rest.

However, these prices must be understood as political. Fair trade's impact rests in large part upon its redistributive potential — the extent to which it shifts capital from retailers and distributors "upstream" along the commodity chain to cooperatives, producers, and in some cases waged laborers. ${ }^{5}$ Since the movement's inception, however, the minimum price levels have come to reflect not a calculation of what small farmers need to sustain family livelihoods, but rather the prevailing balance of power between different groups of participants in the coalition: producers, certifiers, distributors, and retailers both small and large.

After substantial grassroots mobilization by producer groups, FLO agreed to a minor increase in the coffee base prices in 2007 ; they were raised to $\$ 1.35$ per pound for conventional coffee and to $\$ 1.55$ for certified organic (Transfair USA 2007). However, as of this writing, the minimum price would need to rise to over $\$ 2.29$ per pound to recoup its original purchasing power (Bacon 2009).

The concerns over the base prices have emerged within the U.S. as movement-oriented roasters pushed for a raise, and then responded to the small 2008 boost. Just Coffee, for example, argued that the rise in the FLO social and organic premiums was good but inadequate: "however, the base minimum price is still $\$ 1.21$ [now $\$ 1.25$ ] for fair trade coffee. The idea with the 'premium' is that it should be 'extra' cash left over after producers are paid for the value of their coffee and labor, to be invested in community infrastructure...in order for these 'premiums' to work, we have to assume that growers are making money beyond the cash they need for basic survival. We have heard from farmers that this is not always the case" (Just Coffee 2007). In

\footnotetext{
${ }^{5}$ Of course, it is not merely the existence of price premiums per se, but the level of prices multiplied by actual sales volumes, that determines the extent of the redistributive impact.
} 
response, the Cooperative Coffees roasters and the larger Equal Exchange have all chosen to establish their own, higher, minimum prices for coffee, as much as $\$ 2.20$ per pound in the case of Just Coffee. The roaster advocates that the review of FLO minimum prices should "be repeated often, with transparency and democratic participation from diverse stakeholders" (Just Coffee 2007).

\section{4) Certification of Plantations.}

Another point of contention concerns the increasing certification of plantation agriculture in the fair trade system. Fair trade was originally designed as a system explicitly for the benefit of small farmers; in the global South, this meant marginalized peasant producers of tropical export commodities. As fair trade expanded beyond coffee, certifiers occasionally turned to small, progressive estates or plantations to fill the gap. They created a second "modality" in fair trade for waged workers, in which certification is based on minimum labor and safety conditions, allowing workers the right to unionize, payment of national minimum wages, and the payment of price premiums into an independent fund for the benefit of workers, to be managed by an organization jointly run by workers and owners. While the hired labor modality was initially seen as a minor adjunct to small producers, the number and volume of certified products from plantations and estates has skyrocketed in the past few years, as FLO and the NI's have attempted to meet retailers' demands for a greater variety of fair trade products, such as fresh produce and flowers, many of which are sold under "own brand" labels at major retail chains (Barrientos et al. 2007). This has raised concern among some activists and the movementoriented companies, because inclusion of plantation agriculture is seen as key to expanding the role of large corporate agrifood firms in the system. While standards for plantation agriculture are set by FLO, the activities of the NI's largely determine the size of this mode because of their 
licensing function. Transfair USA has played an active role in expanding plantation fair trade, by actively working to bring firms into the system. These developments raise several key questions: Is fair trade primarily a system for and about small producers? What should be the role of the "plantation modality" within the larger fair trade movement? Is fair trade the most appropriate mechanism for holding plantation owners accountable, and for achieving social justice for waged agricultural workers?

Among the criticisms directed at plantation certification is that it opens the door to the most socially and environmentally problematic forms of conventional agriculture, and can give the fair trade imprimatur to corporate "bad actors" with deeply problematic histories of labor rights violations. In seeking a source of bananas for the U.S. market, for example, Transfair USA overtly sidelined social movement participants in order to negotiate directly with number-two banana giant Chiquita (and the international banana union COLSIBA) to certify a corporatelyowned plantation in Honduras, a deal that was ultimately unsuccessful (Raynolds 2007). In 2009, Dole - the world's largest fresh fruit producer and trader, with far fewer unionized workers than Chiquita—did receive Transfair certification for bananas and pineapples produced on its Ecuadoran plantations (The Packer 2009).

Organizations of small producers have strenuously opposed the extension of fair trade certification to plantations. One of the concerns they voice is that their cooperatives will be undercut by the high volumes and economies of scale involved in plantation production, and thus lose their markets. Carmen Iezzi, director of the U.S.-based Fair Trade Federation, charges that "the large companies want to continue working with mass producers like plantations rather than going the tougher route, which is identifying small farmers and buying from them" (quoted in Goigoi 2008a). Other critics add concerns that the benefits to workers are nebulous: national 
minimum wages are a notoriously inadequate benchmark, the "independent" workermanagement organizations have an uneven track record at best; and there is no requirement of unionization (only the right to unionize), leaving the door open for labor rights violations. Indeed, in Colombia - a nation notoriously dangerous for unionists - none of the fair trade certified cut flower plantations is unionized (Goigoi 2008a). This opposition from small producers has met with some limited success: there has been an agreement with FLO to keep four commodities free of plantation certification for the present: coffee, cocoa, honey, and cotton (Renard 2006: 7). However, Transfair USA continues to rapidly expand the number of new fair trade products produced exclusively by the plantation sector (Transfair USA 2008b), shifting the profile of fair trade steadily toward large-scale conventional agriculture. The certifier claims this move fulfills its social justice mission no less than buying from cooperatives: "The disadvantaged majority would be locked out of the market if I were to look for only small farms for bananas and tea," claimed CEO Paul Rice (quoted in Goigoi 2008a).

Yet some critics respond that emphasizing the plantation sector is antithetical to the founding principles of fair trade. After a recent article in the Times of London claimed that workers on Indian fair trade-certified tea estates were not reaping any economic benefits from the certification (Bahra 2009), Equal Exchange responded that "the findings presented in this article only serve to reaffirm our belief that plantations do not belong in the Fair Trade system in the first place... the company believes that 'Fair Trade' needs to mean 'Small Farmer" and that... a joint labor-management council and social premiums cannot in and of themselves correct the huge imbalance of power that exist on a plantation" (Equal Exchange 2009). As the number and volume of plantation-sourced fair trade products increases, the contention between 
these two distinct visions of fair trade within the U.S. movement is likely to become more pronounced.

5) Fairness Along the Supply Chain; Managing the Growth of Fair Trade.

A related issue is the question of what portion of the commodity supply chain ought to be the concern of fair trade standards. The decision to certify Starbucks coffee was particularly galling to some activist groups because the company had long been the target of allegations of labor rights abuses - not only on the Central American plantations from which it purchased, but also at its cafés in the United States. Two rulings by the U.S. National Labor Relations Board found that Starbucks had violated the rights of baristas at its cafes by interfering with union organizing activity (Workers Independent News 2005). The sales of fair trade products by large corporate retailers, while initially somewhat less controversial than directly licensing transnational companies like Starbucks, have also recently become a major point of contention as well. After Wal-Mart introduced three house-brand lines of fair trade certified coffee, labor activists charged that the retailer was engaging in a "fair-washing" strategy. "If Wal-Mart wants to ensure that producers of coffee are paid a living wage," said David Nassar, executive director of the union-funded group Wal-Mart Watch, "it should show the same concern for people who produce the 139,000 other products that they sell at the store" (quoted in Goigoi 2008b). Transfair USA, however, insists that these questions do not fall under its purview. According to the certifier's Corporate Engagement Guidelines, “Transfair's certification and audit system focuses on Fair Trade Certified products, not a company's overall business practices...it is beyond the scope of Transfair's certification model to try to address these concerns." (Transfair USA 2008g). 
A final issue, which underlies most of the others discussed above, is the question of fair trade's growth. What type of growth should the movement pursue, and at what cost? There is a distinction between growth as a means to achieve ethical or moral goals (for example, greater economic justice) or further specific values, versus growth as an end in itself. Even if the goals are clear, however, there is the question of which strategies will best achieve them. In the case of fair trade, the movement-oriented activists and retailers argue for growth with a high bar: strict regulation of corporate participants with an obligation to increase volume percentages over time to work toward a "fully fair" supply. Transfair USA, however, has opted to pursue a different model of social change, involving flexibility, negotiation, and collaboration with corporate licensees - maintaining a lower bar in the pursuit of volume growth as a primary goal. Faced with this reality, some argue that movement-oriented players need to remain focused on their own distinct vision of growth. "To keep Fairtrade from becoming irrelevant to farmers' livelihood struggles," write Holt-Giménez et al., "it is up to the ATOs, enlightened roasterretailers, students, activists, and progressive certifiers to help poor coffee farmers grow not just their market, but their market power; not just their businesses, but their controlling share within the business" (Holt-Gimenez et al. 2007).

\section{SOCIAL MOVEMENT RESPONSES: INSIDE AND OUTSIDE}

As the previous sections indicate, co-optation is not necessarily a linear or uncontested process. Typically, such actions engender various forms of resistance. Several of the recent developments within the fair trade system discussed above demonstrate how social movement constituencies have attempted to "push back" against cooptation and dilution of the initiative, and in some cases have managed to transform setbacks on standards into more ambiguous and ongoing processes of negotiation, and occasionally small victories. 
A simple typology may aid in analyzing the responses to cooptation that have emerged in fair trade. First, faced with attempts to compromise the standards, some social movement groups have organized politically to reverse or halt the weakening, to "defend" the integrity of the standards from within the initiative - that is, while remaining inside (or supportive of) the formal certification system. Second, depending on the degree of cooptation, some other groups and constituencies have chosen to "opt out," to leave the formal certification system entirely and focus their energy instead on building independent or outside alternatives. Finally, a third mode of resistance is also evident: some actors have engaged in both types of strategies (either simultaneously or sequentially), employing an "inside-outside" approach that raises interesting questions about the complementary and/or antagonistic roles of different participants within the same movement.

\section{Inside Responses}

There has been concerted resistance by some actors within the U.S. fair trade system to the corporatization of fair trade and the dilution of standards. This effort has been led by several 100-percent fair trade coffee roasters, including the U.S. movement pioneer Equal Exchange, which lobbied FLO to stop Nestlé's inclusion in the certification system in the United Kingdom (Equal Exchange 2005), and was joined in its criticism by other NGOs and networks in the U.S. These roasters have also aimed to raise consumer awareness of the difference between the movement-oriented, 100-percent fair trade companies and the "dabbling" of the new corporate entrants. Interestingly, the Organic Consumers Association (OCA) - a membership-based advocacy group focusing primarily on protecting and strengthening organic standards - has also entered the fair trade fray, periodically engaging its members in campaigns to push Starbucks to 
purchase higher levels of fair trade certified coffee, most recently in 2008 (Organic Consumers Association 2008).

A second current has focused on what Doherty and Tranchell (2007) term "radical mainstreaming": the development of fair trade companies whose products still bear the official fair trade seal but are distinguished by alternative business models such as worker or producer co-ownership, profit-sharing, or a substantial equity stake by the Southern producer cooperatives, creating substantially more added value for their members. The most prominent such example is the UK-based Divine Chocolate Ltd. (formerly Day Chocolate), which produces Divine Chocolate bars and is 50 percent owned by Ghanaian cocoa producer organization Kuapa Kokoo (Doherty and Tranchell 2005), and which now has a U.S. subsidiary, Divine Chocolate U.S.A. U.S. examples of this approach include fair trade pioneer Equal Exchange, a worker-owned cooperative, and the Cooperative Coffees grouping of twenty-three 100-percent fair trade roasters. While neither has yet provided an equity stake in the company to their producer suppliers, both have chosen to pay well above fair trade minimum prices and have been the most vocal in promoting a vision of "deep fair trade" in the U.S. context.

Nonetheless, given the extent of the grievances by social movement players against Transfair USA and FLO policies, the absence of any coordinated mobilization within the U.S. fair trade movement (and in the North more generally) for changes in fair trade pricing and certification practices is noteworthy indeed. "There is no campaign," note Holt-Giménez et al., "to convert a fixed percentage of any of the major firms' sales to fair or organic trade ... and no hard proposal for using Fairtrade as a pathway to transform the coffee industry's value chain into something more equitable" (2007: 13). This lack of a common agenda for change from within 
the movement greatly limits any efforts to communicate to consumers the nature of the challenges facing fair trade, or to outline potential solutions.

\section{Outside Responses}

Some of the social movement participants in the U.S. fair trade movement have chosen instead to express their frustrations about the certification system by leaving it entirely. In 2004, after working both publicly and behind the scenes to address their complaints with the policies of Transfair USA, five small, 100-percent fair trade coffee roasters (all members of the Cooperative Coffees network) left the Transfair/FLO certification system entirely. One of the defectors, Matt Earley, co-owner of the Madison, Wisconsin roaster Just Coffee, told the Christian Science Monitor that "without people outside the increasingly corporate-friendly Transfair system pushing for the original vision of a better model, [the movement] will be watered down into nothingness" (Rogers 2004). The five companies continued to purchase coffee from fair trade cooperatives and label it as "fairly traded," but no longer used the Transfair label or pay licensing fees, instead giving the money directly to the producer groups in the form of a higher price than that mandated by FLO. ${ }^{6}$ Some of the roasters have associated instead with the Fair Trade Federation (FTF) — a predominantly craft-based NGO — and now affix the FTF label to their products, although it does not represent an independent certification. Just Coffee additionally claims that its coffee is certified for compliance with fair trade standards by the Midwest Organic Services Association, an organic certifier. These breakaway roasters also communicate their claims of fairness to consumers through brand recognition, transparency, and building relations of trust (for example, their contracts with producer cooperatives are posted publicly online). These and other movement-oriented fair trade companies, along with NGO and activist allies, have succeeded in sparking a debate within the U.S. fair trade movement over

${ }^{6}$ One of these five roasters, Dean's Beans, rejoined the Transfair system in 2007 (Green LA Girl 2008). 
the costs of corporatization and cooptation, juxtaposing what they term "Fair Trade Lite" against the notion of "Deep Fair Trade," and disseminating lists of 100 percent fair trade businesses (e.g., Global Exchange 2007). However, one of the five defectors, Dean's Beans, rejoined the Transfair system in 2007. Owner Dean Cycon said that his reasons for returning included a desire to influence Transfair policy from within, and the proliferation of uncertified fair trade claims by non-movement oriented firms: "More and more companies are coming up with their own version of fair trade ... my ability to have a clear message was starting to get lost," stated Cycon (Green LA Girl 2008).

Another type of "outside" response on the part of small producer cooperatives, social movements and non-governmental groups has been to focus on developing domestic fair trade markets and systems within their nations, rather than the traditional South-North exchanges of tropical commodities that characterize the FLO system. These domestic efforts are furthest advanced in the global South, particularly in Mexico, Brazil, and South Africa (Jaffee et al. 2004; Wilkinson and Mascarenhas 2007). This focus on developing domestic fair trade markets is also growing in the U.S. context. Equal Exchange recently debuted a line of non-certified fair trade products from U.S. family farmers (some of whom are cooperativized), including pecans, almonds and cranberries. A set of standards for domestic fair trade has slowly been developed by a coalition of social justice NGOs, sustainable agriculture advocates and farmworker groups. ${ }^{7}$ This effort, the Agricultural Justice Project, initiated a pilot project in 2008 in the upper Midwest region, making labeled "Local Fair Trade" produce from certified farms available to consumers at grocery stores and food coops in Minnesota and Wisconsin. The organizers say they plan

\footnotetext{
7 The groups in the AJP include Rural Advancement Foundation International-USA (RAFI); Comité de Apoyo a los Trabajadores Agrícolas/Farmworker Support Committee; Northeast Organic Farming Association; and Florida Organic Growers.
} 
eventually to expand the standards system nationwide (Agricultural Justice Project 2007; Agricultural Justice Project 2008).

\section{Inside-Outside Responses}

Rather than a binary "inside" versus "outside" question, the dynamic in some of these cases might better be described as an oscillation between instances of corporate cooptation or weakening of the standards and rules on one hand, and episodes of movement activism that aim either to "hold the line" (defend the standards and halt further weakening) or "push back the line" (reverse the weakening and strengthen standards), on the other. Two examples of this dynamic are the contentious and ongoing negotiations within FLO over which products will remain closed to plantation production, and the struggles over the level of fair trade minimum prices - both of which involve U.S. players in substantial roles. A third is the domestic negotiations that took place between Transfair USA and several fair trade NGOs over guidelines for the certifier's engagement with corporations (Transfair USA 2008g). Additionally, some individual participants in these networks have engaged simultaneously (or sequentially) in both inside and outside strategies. The U.S. coffee roasters that left the FLO/Transfair system have continued to dialogue with Transfair USA, urging a series of reforms in exchange for rejoining the formal system.

\section{DISCUSSION AND CONCLUSIONS}

What conclusions might be drawn from this assessment of the landscape of the fair trade movement in the U.S.? I offer a few general observations. The phenomenon of cooptationmanifested as both standards dilution and regulatory capture - has clearly taken place and continues to occur in the context of the U.S. fair trade system. Major changes in any such movement are inevitable as growth occurs and the organizers begin to reach beyond the 
politicized core of "conscious consumers" to a mass consumer audience. Yet the dilution of standards need not be inevitable if the certification body can avoid capture and continue to serve an independent regulatory function, holding licensees to firm conditions that are consistent with the movement's foundational principles.

Attempting to use the market to leverage social change is fraught with difficulty. When an alternative social justice market ceases to be marginal and threatens to affect the bottom line of the major firms in an industry, attempts at cooptation are likely. When mainstream firms participate in a regulatory structure such as fair trade licensing and certification-particularly when they begin to constitute a substantial proportion of sales (and of certifier income) - that body is at risk of regulatory capture, and may experience changes in organizational culture as a result that facilitate further cooptation. In the case of the U.S. movement, and in particular the regulator/certifier Transfair USA, each of these processes is evident, and in some cases quite advanced, as described above.

At the same time, pressure and vigilance by social-movement groups clearly has the potential to make a meaningful impact in limiting, mitigating, or even in some cases reversing these processes. Indeed, some of the movement-oriented groups have played just such a role, at times succeeding in counterbalancing pressures from the large commercial firms to water down standards even further. There is (and has been) an intriguing range of efforts-from actors within and beyond the formal standards system — to protect and/or restore the integrity of the standards undergirding fair trade. Campbell (2001: 362) hopefully observes that "while cooptation cannot be avoided, it need not be framed as posing a stark choice between politically disengaged purity and politically engaged capitulation." Not only can outside and inside strategies be complementary; they also potentially could take greater advantage of what social 
movement scholars term the "radical flank effect," in which the more "extreme" tactics and rhetoric of outside groups in a broad movement can make those of moderate insiders appear reasonable, rendering their efforts more effective. "The presence of more extreme groups," writes Dobson (n.d.: 6), "alters the definition of middle, making former radicals seem merely progressive."

There are a number factors that arguably make the U.S. fair trade case distinctive. First is the question of the initiative's political culture. While the actors who laid the groundwork for fair trade in the United States_-Equal Exchange coffee in particular had a large influence — were as strongly linked with a radical critique of the injustice of global trade as their counterparts in Europe, those actors and perspectives were not successfully incorporated into the "DNA" of the national certification body. Although Transfair USA was initially housed within a progressive trade policy NGO, once it became independent in 1999 and certification began in earnest, these ties were severed. The board of directors has not reflected the composition of the U.S. movement as a whole, with negligible representation by social justice, trade justice or other civil society activist organizations or from 100-percent fair trade firms. This means, among other things, that the certifier has fewer internal watchdogs than many of its counterparts in Europe and elsewhere. The embrace of the corporate sector as part of an aggressive growth strategy came first in the U.S. as well, beginning with the 2000 agreement to certify Starbucks. (The U.K. certifier Fairtrade Foundation entered these waters half a decade later when it extended the certification to Nestlé.) This may be due in part to the absence of countervailing voices within Transfair, and in part to the strong influence of a single individual-Transfair's founder and $\mathrm{CEO}$ - in shaping the organization's policy direction and its institutional culture. Moreover, the U.S. is the home base of many of the largest transnational agri-food firms, including three of the 
"Big Four" companies that dominate the global coffee trade. The U.S. consumer market for fair trade is also the most potentially lucrative, with a huge possibility for growth in demand.

These peculiarities of the U.S. case have several implications for the international fair trade movement as a whole. In many cases, precedents established in the U.S. have effectively "set the pattern" for the entire FLO system. For example, once Starbucks was allowed to enter the certification system with only one percent of its purchases at fair trade terms, the bar was effectively lowered not only on a national but on a global level; no major competitor would likely accept being bound to a higher standard. Likewise, although earlier debates within FLO had partially opened the door to a greater role for plantation and estate products, Transfair USA's aggressive (and ultimately unsuccessful) pursuit of a deal with Chiquita arguably changed the playing field and moved the entire FLO system further toward certification of agribusiness. To the extent that such deals create faits accomplis or "facts on the ground" without opportunity for democratic deliberation by all major stakeholder groups, these instances of standards dilution are very difficult to reverse.

On the other hand, the non-state nature of the fair trade standards also offers intriguing possibilities for the future: the potential is arguably greater here for reversing some of the losses to standards integrity than in a context where standards are codified into law and subject to an even greater degree of regulatory capture. The most obvious such example is the USDA Organic standards, which since their promulgation in 2001 have been altered by Congressional intervention on numerous occasions on behalf of specific industries or even single firms.

Finally, what lessons might the U.S. experience in fair trade offer to fair trade activists and organizations in other consumer nations, as well as to newer social movements focused on achieving economic justice and sustainability in the agriculture and food system? How could 
they best anticipate and avoid some of the problems that have characterized the U.S. case, and how might they (re-)design their governance structures to more effectively guard against cooptation, preventing or at least forestalling the dilution of standards and the capture of the governance bodies by large-scale players? One observation relates to the scale of participants in the system. The fair trade standards contain no explicit stipulations regarding the scale of participants - they are mum on the desirability of large transnational and/or publicly-traded commercial firms entering the system, and attach no special conditions to these players. Yet their large scale has significant ramifications for smaller and mid-sized companies, particularly those selling all or mostly fair trade certified products. They enjoy economies of scale that allow them to undercut competitors on retail price, particularly if they are permitted to participate at minimal volumes. The certification of agribusiness plantations in tea, flowers, and other commodities can directly threaten the income of smaller producers of these same crops. Other initiatives might wish to consider addressing explicitly in their standards the desirability of large-scale enterprises, the conditions of certification (and decertification) and the responsibilities attached to large licensees - perhaps including language obliging them to ratchet up their fair trade volumes to specific levels in defined time frames.

The U.S. fair trade movement also offers insights into the importance of the structure and representativeness of certification entities. Transfair USA's history indicates that the initial decisions that are made regarding the organizational and governance structure of bodies governing market access and certification are crucial. If the original ideological principles and visions of the movement's founders can be incorporated into the bylaws, board and committee structures, lines of authority, and funding mechanisms of these entities, it is at least theoretically possible for the organization and movement to manage the challenges associated with growth, 
while also safeguarding against cooptation. The way that formal and informal power are allocated between different constituencies_-including NGOs, grassroots activist groups (e.g., students), distinct groups of retailers (both non-profit and for-profit), as well as other sectorswill to a great extent determine the range of policy possibilities. To the largest extent possible, formal governance power should be reflective of the actual breadth and diversity of the movement itself. Financial structures should be designed with an effort to avoid the potential for conflicts of interest-e.g., the increased influence of large-scale firms over certifier budgets. A clear-eyed analysis indicates that the U.S. fair trade certification standards - the rules of the game- have indeed been rendered more friendly for conventional corporate actors. However, it is also apparent that the responses by movement activists (in both their inside and outside manifestations) to the dilution of standards and to the capture of the certification body, have in many cases kept the standards far stronger than they otherwise would have been. In this sense, the development of fair trade in the U.S. could be read either as a cautionary tale, or as an unfolding story of contestation with the ending as yet unwritten. 


\section{REFERENCES}

Agricultural Justice Project. (2007). New Pilot Food Label Certifies Social and Environmental Stewardship (Press Release). Minneapolis, MN: Agricultural Justice Project.

---. (2008). Social Stewardship Standards in Organic and Sustainable Agriculture: Full Standards Document. Minneapolis, MN: Agricultural Justice Project.

Allen, P. and M. Kovach. (2000). "The capitalist composition of organic: the potential of markets in fulfilling the promise of sustainable agriculture." Agriculture and Human Values 17(3): 221-232.

Bacon, C. (2009). "Who Decides What is Fair in Fair Trade? An Action Research Approach to Connect Agro-environmental Governance with Livelihood Vulnerabilities in the Americas." Paper presented at American Association of Geographers Meeting, Las Vegas, NV, March 22-27.

Bacon, C., CAFENICA and C. Coordinadora Latinoamericana y del Caribe de Pequenos Productores de Comercio Justo. (2006). Estudio de Costos y Propuesta de Precios para Sostener el Café, las Familias Productores y Organizaciones Certificadas por Comercio Justo en America Latina y el Caribe: Coordinadora Latinoamericana y del Caribe de Pequeños Productores de Comercio Justo, CLAC. .

Bahra, P. (2009) "Tea workers still waiting to reap Fairtrade benefits." The Times (UK). http://www.timesonline.co.uk/tol/news/uk/article5429888.ece. Retrieved January 8, 2009.

Barrientos, S., Michael E. Conroy and Elaine Jones. (2007). Northern Social Movements and Fair Trade. in Fair Trade: The Challenges of Confronting Globalization. L. T. Raynolds, D. Murray and J. Wilkinson, Ed. New York: Routledge: 51-62.

Busch, L. and C. Bain. (2004). "New! Improved? The Transformation of the Global Agrifood System." Rural Sociology 69(3): 321-346.

Campbell, D. (2001). "Conviction seeking efficacy: Sustainable agriculture and the politics of co-optation." Agriculture and Human Values 18(4): 353-363.

Dobson, C. (n.d.) "Social Movements: A Summary of What Works." http://www.vcn.bc.ca/citizens-handbook/movements.pdf. Retrieved July 28, 2008.

Doherty, B. and S. Tranchell. (2005). "New Thinking in International Trade? A Case Study of The Day Chocolate Company." Sustainable Development 13(3): 166-176.

Doherty, B. and S. Tranchell. (2007). ""Radical Mainstreaming" of Fairtrade: the Case of The Day Chocolate Company." Equal Opportunities International 26(7): 693.

DuPuis, M. and S. Gillon. (2009). "Alternative modes of governance: organic as civic engagement." Agriculture and Human Values.

Equal Exchange (2005). Fair Trade Coffee Pioneer Questions Nestle Entry into Market: Equal Exchange Cites Multinational's 'Credibility Gap'. West Bridgewater, MA.

---. (2009). "Equal Exchange Joins Critique of Fair Trade Plantations: Tea estate workers voice skepticism over ethical claims." http://www.equalexchange.coop/equal-exchange-joinscritique-of-fair-trade-plantations. Retrieved March 3, 2009.

FLO. (2008). Annual Report 2007: An Inspiration for Change. Bonn, Germany: Fairtrade Labelling Organizations International.

Fridell, G. (2007). Fair Trade Coffee: The Prospects and Pitfalls of Market-Driven Social Justice. Toronto: University of Toronto Press. 
Fridell, M., I. Hudson and M. Hudson. (2008). "With Friends Like These: The Corporate Response to Fair Trade." Review of Radical Political Economy 40(1): 8-34.

Gamson, H. (1968). Power and Discontent. Homewood, IL: Dorsey Press.

---. (1975). The Strategy of Social Protest. Homewood, IL: Dorsey Press.

Gereffi, G., J. Humphrey and J. Sturgeon. (2005). "The Governance of Global Value Chains." Review of International Political Economy 12: 78-104.

Gereffi, G. and M. Korzeniewicz, Eds. (1994). Commodity Chains and Global Capitalism. Westport, CT and London: Praeger.

Global Exchange (2007) "100\% Fair Trade Companies." http://www.globalexchange.org/campaigns/fairtrade/coffee/retailers.html. Retrieved July 29, 2008.

Goigoi, P. (2008a). "Is Fair Trade Becoming 'Fair Trade Lite'?" Business Week, June 18.

---. (2008b). "A Wal-Mart PR Issue Brews Anew." Business Week, April 1.

Goodman, D. and M. Goodman. (2007). Localism, Livelihoods and the 'Post-Organic': Changing Perspectives on Alternative Food Networks in the United States. in Alternative Food Geographies: Representation and Practice. D. Maye, L. Holloway and M. Kneafsey, Ed. Oxford, UK: Elsevier Science: 23-38.

Green LA Girl. (2006). "Certification challenges XIII: 5\% - requirement vs. recommendation." www.greenlagirl.com/2006/03/24/certification-challenges-xiii-5-requirement-vsrecommendation. Retrieved March 3, 2009.

--- (2008). "Why Dean's Beans got fair trade certified — again " http://greenlagirl.com/2008/01/15/why-deans-beans-got-fair-trade-certified-again/. Retrieved February 21, 2009.

Guthman, J. (2004a). Agrarian Dreams: The Paradox of Organic Farming in California. Berkeley, California: University of California Press.

---. (2004b). "The Trouble with 'Organic Lite' in California: a Rejoinder to the 'Conventionalisation' Debate." Sociologia Ruralis 44(3): 301-316.

Holt-Gimenez, E., I. Bailey and D. Sampson. (2007). Fair to the Last Drop: The Corporate Challenges to Fair Trade Coffee. Oakland, CA: Food First.

Jaffee, D. (2007). Brewing Justice: Fair Trade Coffee, Sustainability, and Survival. Berkeley, California: University of California Press.

Jaffee, D. and P. Howard. (forthcoming). "Corporate Cooptation of Agrifood Alternatives: Lessons from Organic and Fair Trade." Agriculture and Human Values.

Jaffee, D., J. R. Kloppenburg and M. B. Monroy. (2004). "Bringing the "Moral charge" home: Fair trade within the north and within the south." Rural Sociology 69(2): 169-196.

Just Coffee. (2007). "FLO Announces a Raise." http://justcoffee.coop/node/1059. Retrieved March 2, 2009.

Laffont, J.-J. and J. Tirole. (1991). "The Politics of Government Decision-Making: A Theory of Regulatory Capture." Quarterly Journal of Economics: 1089-1127.

Mutersbaugh, T. (2005a). "Fighting standards with standards: Harmonization, rents, and social accountability in certified agrofood networks." Environment and Planning A 37(11): 2033-2051.

---. (2005b). "Just-in-space: Certified rural products, labor of quality, and regulatory spaces." Journal of Rural Studies 21(4): 389-402. 
North, R. (2008). "On Fair Trade "Fig Leaves": Equal Exchange speaks out on abuse of the Fair Trade system." http://www.wedge.coop/newsletter/article/630.html. Retrieved February 28, 2009.

Organic Consumers Association (2008) "Tell Starbucks We Want Fair Trade, Not Greenwashing." Organic Bytes. http://www.organicconsumers.org/bytes/ob139.cfm. Retrieved July 30, 2008.

Patriana, Z. (2008). "Leading Fair Trade Roaster Critiques Starbucks' Decision." Change.org Fair Trade Blog http://fairtrade.change.org/blog/view/leading_fair_trade_coffee_roaster_critiques_recent_ starbucks decision. Retrieved March 31, 2009.

Raynolds, L. T. (2007). Fair Trade Bananas: Broadening the Movement and Market in the United States. in Fair Trade: The Challenges of Confronting Globalization. L. T. Raynolds, D. Murray and J. Wilkinson, Ed. New York: Routledge: 63-82.

---. (2009). "Mainstreaming Fair Trade Coffee: From Partnership to Traceability." World Development 37(6): 1083-1093.

Raynolds, L. T., D. Murray and A. Heller. (2007). "Regulating Sustainability in the Coffee Sector: A Comparative Analysis of Third-Party Environmental and Social Certification Initiatives." Agriculture and Human Values 24: 147-163.

Raynolds, L. T., D. Murray and J. Wilkinson, Eds. (2007). Fair Trade: The Challenges of Transforming Globalization. New York: Routledge.

Raynolds, L. T. and J. Wilkinson. (2007). Fair Trade in the Agriculture and Food Sector: Analytical Dimensions. in Fair Trade: The Challenges of Transforming Globalization. L. T. Raynolds, D. Murray and J. Wilkinson, Ed. New York: Routledge.

Reed, D. (2009). "What do Corporations have to do with Fair Trade? Positive and Normative Analysis from a Value Chain Perspective." Journal of Business Ethics(86): 3-26.

Renard, M.C. (2005a). "Quality Certification, Regulation and Power in Fair Trade." Journal of Rural Studies 21(4): 419-431.

--. (2005b). "Quality certification, regulation and power in fair trade." Journal of Rural Studies 21(4): 419-431.

---. (2006). "Recomposición de la Gobernancia en el Comercio Justo." Paper presented at Coloquio ALTER 2006, Baeza, Jaén, Spain, October 18-21.

Renard, M. C. and V. Perezgrovas. (2007). Fair Trade Coffee in Mexico: At the Center of the Debates. in Fair Trade: The Challenges of Transforming Globalization. L. T. Raynolds, D. Murray and J. Wilkinson, Ed. New York: Routledge: 138-156.

Rogers, T. (2004) "Small Coffee Brewers Try to Redefine Fair Trade." Christian Science Monitor, April 13.

Selznick, P. (1949). TVA and the Grass Roots. New York: Harper.

Stigler, G. (1971). "The Theory of Economic Regulation." Bell Journal of Economics and Management Science 2: 3-21.

The Packer (2009) "Dole Debuts Fair Trade Pineapples, Bananas " The Packer. http://thepacker.com/Dole-debuts-Fair-Trade-pineapples-bananas/Article.aspx?articleid=843790\&feedid=217. Retrieved October 24, 2009.

Thompson, C. J. and G. Coskuner-Balli. (2007). "Countervailing Market Responses to Corporate Co-optation and the Ideological Recruitment of Consumption Communities." Journal of Consumer Research 34: 135-152. 
Transfair USA. (2007). Press Release: FLO International Raises Fairtrade Price for Coffee Farmers. Oakland, CA: Transfair USA.

---. (2008a). "Board Members." http://www.transfairusa.org/content/about/board.php. Retrieved March 2, 2009.

---. (2008b). "Fair Trade Products." http://transfairusa.org/content/about/products.php. Retrieved January 11, 2009.

---. (2008c). "Frequently Asked Questions - Advanced." http://transfairusa.org/content/resources/faq-advanced.php. Retrieved May 23, 2008.

---. (2008d). "One Billion Ways to Be Fair: U.S. Fair Trade Certified Product Sales Surpass $\$ 1$ Billion." http://transfairusa.org/content/about/pr/pr_080903.php. Retrieved February 20, 2009.

---. (2008e). "Starbucks, TransFair USA and Fairtrade Labelling Organizations International Announce Groundbreaking Initiative to Support Small-Scale Coffee Farmers." http://www.transfairusa.org/content/about/news/n_081028.php. Retrieved January 11, 2009.

---. (2008f). Transfair USA--2007 Annual Report. Oakland, CA: Transfair USA.

---. (2008g). "TransFair USA Corporate Engagement Guidelines." http://www.transfairusa.org/content/Downloads/resources/TFUSA_Engagement_Guideli nes.pdf. Retrieved May 12, 2009.

---. (2009). Almanac: 2008. Oakland, CA: Transfair USA.

Transfair USA and Starbucks Coffee. (2009). Starbucks, TransFair USA and Fairtrade Labelling Organizations International Join in Support of Small-Scale Coffee Farmers Through a \$20 Million Loan Program.

Tucker, A. (2006). "Fair Enough?" New Internationalist(395): 7.

Wilkinson, J. and G. Mascarenhas. (2007). Southern Social Movements and Fair Trade. in Fair Trade: The Challenges of Confronting Globalization. L. T. Raynolds, D. Murray and J. Wilkinson, Ed. New York: Routledge: 125-137.

Workers Independent News (2005) "NLRB Rules in Favor of Starbucks Union." Workers Independent News. www.laborradio.org/node/391. Retrieved December 30, 2005. 